DOI https://doi.org/10.36059/978-966-397-111-7/152-172

\title{
THE LESSONS OF HISTORY AND POLITICS: PROGNOSTIC FUNCTION OF THE MODERN POLITICAL STUDIES OF INTERNATIONAL RELATIONS
}

\section{Chekanov V. Yu.}

\section{INTRODUCTION}

Modern humanities underline persistently the difference between the science of previous centuries as influenced greatly by the moral philosophy on behalf of social requirement and the contemporary humanitarian studies stem out of practical, even prosaic everyday needs. That is why the personality and writings by Niccolo Machiavelli have been highly appreciated in modern times; no illusions survived two world wars with all the genocides, political repressions and totalitarianism throughout Europe.

In the period before the aim to create logically non-contradictory and smooth picture of the world was the main implied reason to develop humanities. Nowadays these sciences go on to exist even after failures to create the working models of the world; the description of the world isn't the aim anymore. It has changed now and re-shaped to fulfill practical tasks and to meet practical requirements. The humanitarian knowledge becomes more down-on-the-ground and appropriately less "high". It is orientated now more onto gathering, systematization and interpretation of the data than onto working out some generalizing theories claiming to explain the whole world. The phenomena are picked up according to the certain procedure but no obligatory generalization for them is provided anymore. They get their description but not an explanation. The modern sciences are never afraid to recognize the lacunas inside.

The political science is entirely a brainchild of XX century. It started at the phase when the chances to create full picture of how policy works have been negated. In the political science nowadays various theories of it co-exist claiming to meet the public requirements. None of these theories is aimed to cover the parallel ones making them superfluous. The entire

\footnotetext{
${ }^{1}$ Смит Роджер. История гуманитарных наук. Р. 361, 385, 390.
} 
structure of the discipline becomes asymmetric and clumsy cause of simultaneous presence of very different methods and approaches in it. This is the feature of rather "theory" than "science"; generalization occupies no significant place in $i^{2}$. Different methods and approaches (sometimes with all their theoretical backgrounds) are neighboring within - what for?

The only accessible answer here is: to meet practical requirements. This task doesn't demand the full picture and even the strict definition of subject (in fact, there is no strict definition of it in political science yet). The opinion that the political science is just "theory" of unidentified structure and of lacking fundamentals is not our pure invention. These accusations accompanied the establishment of political science from the very start. They decrease its ambitions everywhere except for the USA (where things turned out differently in some non-theoretical reasons). In the USA theoretical status of the discipline is out of discussion. In postSoviet countries there is special term "politology" to describe the scientific meaning of this relatively "new" branch of knowledge. Of course, this local peculiarity doesn't influence the international significance of the discipline.

The task of this article is to examine the place of prognostic function within the political theory on whole; for it we have to research the role of prognosis in the decision-making process and to analyze the place of expectations for future in political programs. The limits for our research are put by choosing the field of international relations. The reason for it is that here the entirety of working functions may be achieved via head-tohead discussion only (two and more opposing expectations meet and what is left in a bottom line is a result of conflicting projects' clash).

This research is a sort of theory of science, and the problem in this key was barely looked ever. Scientists and historians of science concentrate usually on the actual trends and events (not on their prospects) never continued into future where unidentified bit of material lies. However, the political theory in the field of international relations suggests the branch devoted to the prognosis function exclusively: theory of mathematic games created to modulate some possible outcome of

\footnotetext{
${ }^{2}$ Цыганков П.А. Теория международных отношений. Р. 19-27.
} 
dangerous international situation's further development. The results of these games are analyzed thoroughly and figurate in political documents concerning pre-played situation, although they have no normative meaning and do not match to any kind of scientific knowledge where futurology is forbidden strictly.

On the other hand our look is important for its methodological character dealing with appreciation of existing methods and evaluating the need of working out new ones.

\section{The roots and origins of political theory}

The concept of "international relations" as we know and use it isn't very old invention: longest periods of history of mankind full of international conflicts, wars and supporting diplomatic activity weren't covered with any theoretical grounding it. The first formula of it has been invented at the turn of XVIII - XIX centuries by English philosopher Jeremy Bentham $(1748-1832)^{3}$. Over a century after it this concept was understood routinely: just as interstate relations. The new additions of notions like "global community", "global market" and "global order" have been made in XX century already and fixated the new reality requiring new concepts and working methods. These methods came in the mid XX century from newly established and heavily mathematized cybernetics ${ }^{4}$. The very first use of it was connected with making scenarios for virtual "war games" played in NATO military headquarters to work out recommendations for further conduct with opponent - USSR and its allies from the Warsaw Pact.

It is well-known that the main failing of political theory is the impossibility in principle to possess all the sources needed to make a veritable conclusion on the certain issue. Until the political situation is on, the most important sources are classified in strategic reasons or inaccessible due to their allocation abroad; but the need of them is inevitable. Lots of research technics to reconstruct them were invented. It caused the appearance of numerous computer reconstructions. From the very beginning - since 1950 s - these reconstructions have been done in

\footnotetext{
${ }^{3}$ Смит Роджер. Op. cit. Р. 210.

${ }^{4}$ Современные буржуазные теории международных отношений. Критический анализ / Под ред. В.И. Гантмана. Р. 45-50.
} 
digital form usually to enable immediate transmission of them to computer as data to count the chances out. The widening of digital data instead of ideologically loaded documents drove the political theory to deideologization and thusly to pluralism from the monopolistic dominance of American "political realists" during first ten years of the Cold War.

The new epoch was characterized by the prevailing of indicative methods to shape the processes not having any verbal description yet. The pioneering this novelty is attributed usually to Karl Deutsch (1912-1992), one of the prominent analysts in the field ${ }^{5}$. Using this approach, he provoked greatly the recent situation in international relations' science: dominance of non-verbal methods led to the rise of new approaches; each of them claimed to occupy its place as workable one. The whole political science started to divide into many independent sections applicable in concrete situations but resistible to any try to put them within one framework. The theory stopped to become scientific and left divided into separate methodological directions; their belonging to one space of "political theory" became just declarative. It wasn't supported by any normative disposal within the discipline. The contemporary situation in the discipline is difficult to overcome and to get rid of it: it has long history, its own logic of evolution and successes in prognoses of international situation of bipolar world from 1950 to 1990s.

The strategies coexisting in the field were withstanding each other very often. For instance, K. Deutsch interpreted his own method as an assistance in choosing whether strategy to abstain involvement into some situation or strategy to get in it to take over the control of its development. For George Modelski the purpose of involvement was formulated differently and led to different results: to intrude to take over the further steps of opponent state and to control it eventually. Of course, there is much difference between controlling "development of the situation" and "opponent state".

Each method had not only its own argumentation but - what's more important - the statistically and mathematically grounded methodology of its own. The choice which method is better depended since then not upon

\footnotetext{
5 Merritt Richard L., Russett Bruce M., Dahl Robert A. Karl Wolfgang Deutsch // The National Academies Press. URL: http:// books.nap.edu/html/biomems/kdeutsh.html\#FOOT4
} 
their comparative potency but upon the voluntary (and very often nonlogical) choice of certain politician: to rely upon it or not. Since 1950s political theory existed in the situation when no method in it was ever negated or at least doubted ${ }^{6}$. It made it sizeless and clumsy as a whole but working successfully in all of its separate parts. The result of state of things James N. Rosenau (1924 - 2011) characterized as "pre-theory": prognostic aspect of political theory wasn't verbalized and just was reduced to defining variables influencing the exterior policy of the state under research. The best way of research was imitation ${ }^{7}$.

\section{The prognosis and its inevitability in political practice}

Imitative methods were introduced massively into prognosis of international situation. It meant that no actual facts (like the ones we call "physical facts" or "historical facts") were known precisely but they were used as alleged ones according to the probability counted by the game computer.

The next failing was even more important. All the situations the mankind was in at the moment of analysis had to be taken as final ones. It looked like all of them were endings of some event consequence. In fact, only minority of them really was... but there was no way to discern these ones from the others going to continue and to develop in future. So, all the events occurred before should be seen as preconditions of some point declared the final one. The intermediate situations had to be understood as endings for the previous event consequences. No possible future developments for these "final" points could be taken into account. The aberration of facts was inevitable however its negative outcomes weren't seen because of any methodology able to look into the future.

It resulted into decrease of practical value of prognosis unless situation changed. Such a political theory worked successfully under conditions of pending balance situation (like the Cold War). The most veritable prognoses enabled prediction for $3-5$ years. As we know no mathematic method could predict the situation of ruined balance like the one occurred in late 1980s after the crisis of communist system in the

\footnotetext{
${ }^{6}$ Современные буржуазные теории международных отношений. Критический анализ. Р. 31.

${ }^{7}$ Ibid. P. 311.
} 
USSR. All the methods for counting out probabilities turned out absolutely helpless in predicting the decline of the USSR.

This event was absolutely unpredicted surprise for all political analysts (according to K. Booth). The year 1989 was a sort of turning point for political theory - its possibilities to predict further event have been doubted since then; the bipolar coordinate system of previous Cold War epoch vanished causing number of crucial outcomes for political analysis $^{8}$.

It turned out suddenly that Cold War wasn't situation only. It was the research paradigm for political theory enabling it to self-identify itself as "science". The end of XX century found this situation changed forever.

$\mathrm{K}$. Booth named 5 reasons why political analysts never interested themselves in future during the Cold War period:

1. Dominance of the "eternal present time" paradigm.

2. The base of sources was reduced down to official press releases. No classified papers involved.

3. Political theory was developed mainly in the West. It reflected its reluctance to admit any possibility of future worse than Western present time.

4. International analysts tried to influence the political practice of governments.

5. Terminology was hypocrite describing post-1945 situation as "peaceful" but hiding local wars with 20000000 perished in the "Third World",

The approach of K. Booth to the description and explanation of the events and their concern to the political theory sounds adequate ("challenge to ignorance") although not enough to start changes. He called to the "rethinking" of political theory's background; this call itself sounded like the echoing post-bipolar paradigm influenced in many issues by Soviet "Perestroika" with its slogans to "start changes from yourself". The real need of the moment was however to free from any paradigms and to try just to open to the unknown future, but was there any to do it? Definitely no.

\footnotetext{
${ }^{8}$ Бус Кен. Вызов незнанию: теория международных отношений перед лицом будущего // Теория международных отношений на рубеже столетий. Р. 334-335.

${ }^{9}$ Ibid. P. 337-340.
} 
The experience of 1990 s revealed considerable similarity to the research optimism of 1960s (based upon the possibility to influence governmental policy by practicing analysts) and the same quality of work. Overshadowed with the menace of Cuban missile crisis of 1962 mankind in that period was ready to believe to any recipe promising to wipe the threat "out of sight, out of mind". At that time there was popular slogan of global government usually scheduled from growing role of the UNO. Under its aegis the step-by-step disarmament could be achieved by 1980 . That was a common belief of $1960 \mathrm{~s}^{10}$. There were three sources of it:

1. The belief in the UNO and its possibilities under impression of the UNO success in overcoming Congolese crisis in 1961.

2. The fashioned ideas of future global government enabled with the growing role of computers.

3. The expectations to have gradual disarmament in future ever growing after Cuban missile crisis had been solved successfully.

The three unpredicted outcomes of these sources killed the optimism of 1960 s but so tenderly, that some of new tendencies weren't spotted for a long time:

1. The solution of Congolese crisis turned out to be the only successful action provided by the UNO throughout upcoming decades. More often the UNO was urged to send "blue helmets" into conflict region to freeze the situation preventing it from worsening. After dozens of these experiments the UNO gradually transformed into global bureaucracy commanding peacekeeping troops all over the world. No chances for its transformation into effective world's government were seen from 1970s. The idea of this government survived its time only in some classic novels and movies of sci-fi genre.

2. The vector of computer technologies' development didn't match up with the expectations of 1960s; the projects of creations of big computers taking over governance functions from human beings weren't put into practice. The fundamentals of political ruling remain intact hitherto.

3. The current events of 1970 s buried the hopes to observe the stepby-step order prescribed in the first treaties for nuclear disarmament. The

10 Кларк Греневиль, Сон Луис Б. Достижение всеобщего мира через мировое право. Два альтернативних плана // Теория международных отношений на рубеже столетий. Р. 115-131. 
turn from Détente to the second "edition" of the Cold War in the late 1970s were the crucial points there. The development of nuclear-free world encountered number of difficulties in the way of its realization and even more: the situation in early 1980s resulted into the growth of the new and yet unpredicted form of "track two diplomacy" when the peoples of Europe guided by some political parties like "Greens" took over the control at the nuclear disarmament in their countries and protested against deployment of American missiles with nuclear warheads in their home countries.

The works by international analysts of the period thus lost their value (the prognostic value particularly) cause no future trend was predicted right (long before 1989 when the flop with the prognosis of Warsaw Pact dissolution opened eyes that something goes wrong in the political theory) ${ }^{11}$.

But what should be underlined, it's the fact that methodological conceptions by the creators of political theory didn't lose their value and were appreciated as the achievements of the period. So their reduced workability never doubted their status and place in the textbooks of political science. The fact this value can be called just "historical" never used to be underlined hitherto.

The upcoming changes in realizations of some 1960s provisions were hailed as progressive although unpredicted moves. The current events became chaotic and the only sign of order was the remaining framework of bipolar withstand. Anything apart from it lost its shape by the end of 1960s causing the wave of "conservative revolutions" in the West (with the exception for France) in the early 1980s. The predictability of situation was lost and still remains the same: "progressive" forces in European countries opposing to the nuclear energetics, spread in 1980s (after Chernobyl catastrophe of 1986 especially). They moved gradually to support the Russian Federation in early 2000s because the depended upon its fuels delivered from Siberia. The countries not so "progressive" towards anti-nuclear movements have established their own nuclear energetics (like France) and thus became more sustainable to the challenges of the new millennium.

11 Кларк Греневиль, Сон Луис Б. Достижение всеобеего мира через мировое право. Два альтернативних плана // Теория международных отношений на рубеже столетий. Р. 115. 
The new approach should be considered "ideological" although positioned contrary by its creators. However its prominent features contradict to idea behind "global government": the discrepancy in the level of economic, social and political development doubted the expediency of uniting such different parts under one aegis and made their unification ineffective; the preconditions for these unification weren't accounted properly too and no attention was paid to some real factors (although not visible at the beginning ${ }^{12}$ ).

In fact, no rethinking would help here; the source of mistake comes out from the discrepancy between scientific analysis with its special requirements and everyday life requiring something different. The above mentioned ambition of political analysts to influence practical actions played its harmful role. In everyday life people do thinking of life and making life plans simultaneously; in science there are various procedures usually never crossing. There would be analog to making life plan as a sort of "futurology" but it wasn't allowed to incorporate into science on whole as a fake.

Correct. But not for political theory where it was incorporated more or less successfully since 1947 when the "theory of games" has been inserted into discipline as a planning of war games. It was crucial for prognosis of bipolar situation's development of the early Cold War. This theory was created by J. von Neumann and O. Morgenstern to meet the practical needs of war planning ${ }^{13}$. The reality was characterized by the lack of quantitative data, thus the data missing had to be substituted by provisional data given optionally (several alternative variants at once). The only chance to count out all the probabilities was to get the digital machinery involved. Lots of technics to work with provisional data arrived into newly developed discipline destroying its scientific structure and making it absolutely different from any other "true" science.

The first war games were called "crisis games" or "voluntary political games" oriented onto purely hypothetic situations. Their development in the late 1940s was explosive cause of common belief that Western superiority in computer field will turn immediately into strategic

\footnotetext{
${ }^{12}$ Merritt Richard L., Russett Bruce M., Dahl Robert A. Merritt Richard L., Russett Bruce M., Dahl Robert A. Op. cit.

${ }_{13}$ Современные буржуазные теории международных отношений. Критический анализ. Р. 50; Цыганков П.А. Теория международных отношений. Р. 71.
} 
advantage in the real Cold War. The game segment occupied thus the position unparalleled by situation in any other science before. The modeling occupied in this discipline much more place than in any other.

This game segment inside the political theory had nothing to do with its theoretical background: no scientific theory can justify presence within the science obligatory and optional parts at once. But it didn't mean that obligatory parts weren't developed too: the descriptive parts of political theory went on creating serious fundamentals for analysis.

Why the political theory survived this killing situation? Mostly it happened because the descriptive ("obligatory") parts of it developed too. During 1950s and 1960s particularly the data of sociology and psychology were accepted by political theory: not as game data but to improve the grounds of it as a science ${ }^{14}$. The game playing didn't disappear due to the Cold War was still on. The continuation of war games playing was supported by considerable development of the discipline in the direction of the full-fledged science. The description of factors influencing policy making and the research of driving motifs behind made giant steps during 20 years. The game playing could progress only in pace with digital technologies' development or by taking into account more variables borrowed from sociology and psychology. It still existed in the political theory but the specific gravity of it changed.

So the use of mathematic methods of modeling caused the separation of theoretical and practical elements of science. It's because modeling meets practical needs better than theory. That is why in the period up to 1990s the presence of it was justified absolutely: digital methods were instruments to provide prognostic researches for governments of states involved into the Cold War. But we can't forget that none of these methods became normative part of it; theoretical constituent of political theory resisted to it mighty. The practical side of theory draws interest of practicing politicians; the theoretical side is more important for professional scientists.

That means that prognostic function is required in practical purposes; however it is not recognized at all by professionals on the theoretical side of the discipline.

\footnotetext{
${ }^{14}$ Современные буржуазные теории международных отношений. Критический анализ. Р. 38,42
} 


\section{The new approaches}

The majority of states where political analysis is practiced don't recognize it as a profession: for instance, Ukraine ${ }^{15}$. The cause of it is connected with the relative accuracy of the prognosis. It never reaches $100 \%$. Even the luminaries like Karl Deutsch could provide precise prognosis for lesser time distance only. For instance, after the withdrawal of France from the military organization of NATO in 1966 K. Deutsch and his collaborators have been assigned to forecast the prospects of European integration under the new conditions. The veritable prognosis they dared was of 10 years penetration into future. It was performed with no use of mathematical modeling but exclusively on the basis of content analysis of publications concerning the topics examined (the content of most frequently used words, phrases and expressions in politicians' interviews since 1953$)^{16}$. This was the innovation put by K. Deutsch into practice to substitute to mathematic modeling which occupied considerable place after World War II ${ }^{17}$.

However the new tendencies never made war games playing disappear: the public request to the discipline expressed by politicians was to have the prognoses, not the explanations of "how policy works". 1960s provided political theories with new directions for this explanation but war games weren't driven out by them ${ }^{18}$. Instead of direct confrontation of methods the things turned to indirect competition. The newest up-to-date contributions were:

- the scenario method combining prognosis with building the mental models of possible situation's development according the sanity;

- the "Delphic" method based upon the discussion of experts controlled by some competent body to reveal the discrepancy in vision of problem between this body and experts recruited.

These methods (especially the last one) were more open to the opinion of experts in case of their contradiction to the basic directive of the control body. Previously the topics and purposes of experts' involvement have been fully defined by the body; experts just worked

\footnotetext{
${ }^{15}$ Класифікатор професій ДК 003: 2010. Р. 330, 459.

16 Deutsh Karl, Edinger Lewis, Macridis Roy, Merritt Richard. France, Germany and the Western Alliance P. 214, 219, 230.

${ }^{17}$ Merritt Richard L., Russett Bruce M., Dahl Robert A. Merritt Richard L., Russett Bruce M., Dahl Robert A. Op. cit.

${ }^{18}$ Цыганков П.А. Op. cit. Р. 69.
} 
according to the scenario given and never allowed to doubt the usefulness of it on whole. But in modern times the things started to change. The new methods had the meaning of auxiliary methods: not prognostic itself, it served just to direct the discussion ${ }^{19}$. Another feature added was the accent removing from possible ways of development of situation to the viewing it by politicians and experts. On the one hand it led from future to present situation, but on the other it added the new dimension to the prognostic function of international relations' science: the understanding that future decisions by politicians depend strongly upon their present views $^{20}$. That opened doors to the new theories and new directions like the analysis of decision making process etc.

The new mantle of political theory was much more modernist. It interpreted policy as a field where different actors cooperate (French philosopher R. Aron called them "political units"). In 1971 G. Rosenau highlighted 6 levels of political units:

- Individuals;

- Positions and roles;

- Structure of the government;

- Society ruled by the government;

- System of relations of national state with other sides of international relations;

- Global system.

Since then the analysis and prognosis of international relations have transformed into the exploration of all possible relations of actors on these 6 levels. Basically they take place on 3 levels:

- Cast (elements composing the structure);

- Interior system (elements connected within the frame);

- Exterior system (elements and their structure connected with outer environment).

In general these levels stipulate all kinds of possible relations. The further determining parameters and factors to deepen the analysis were worked out on a basis of these fundamentals. They enable to include territory, population, political regime, level of population's literacy and technical literacy in particular, morality and life optimism of the society

\footnotetext{
${ }^{19}$ Цыганков П.А. Op. cit. Р. 59.

${ }^{20}$ Ibid. P. 54.
} 
and nation's place in the international system. All of these factors may be displayed digitally and their influence onto exterior policy may be counted out too. It can help in forecasting further changes in policy ${ }^{21}$.

However this impressive approach revealed its failings very soon. Its biggest flaw was the impossibility to use both interior and exterior factors with the same reliability. Exterior factors are more vulnerable to the outer influences produced by either neighboring states or global trends. Sometimes they are sustainable but sometimes are not. To count out the probability of it was futile, and the acceptability of the new approach was decreased respecting.

To omit the negative outcomes, the exterior and interior factors there were declared equal but the issue was if they were equal indeed. Practically the interior factors gradually took the advantage in analysis making cause of their respective easiness to be taken into account.

The dominance of interior factors became clear soon. The system analysis turned up helpless to predict liberation wars in the countries of the "Third World", especially the war in Vietnam. The interior stability in Southern Vietnam was guaranteed by presence of American troops but the constant infiltration of partisan groups from the North provided countless exterior factors pulling down all American strategy to stabilize region ${ }^{22}$.

The next prognostic methods were more inventive but more helpless at once: there was a plan to build ideal models corresponding to real prototypes in all smallest bits where all their possible interactions had to be accounted. Anyway the effectiveness of all methods proposed never reached $100 \%$.

There is popular branch of mathematics called game theory (term "popularity" in case of mathematics means the use of its branches to provide non-mathematical sciences with research tools). War games of 1940s entitled similarly were related with it closely. The new trends in political theory revealed the main flaw of usage of the game theory in prognosis: it was workable in case of rational conduct of opposing sides. But this was far from reality. In fact, many international actors act irrationally, especially non-governmental groups prone to remain in

\footnotetext{
${ }^{21}$ Антюхина-Московченко В.И., Злобин А.А., Хрусталев М.А. Основы теории международных отношений. Р. 68-70.

${ }^{22}$ Цыганков П.А. Ор. cit. Р. 65.
} 
constant opposition to any official initiative and states with authoritarian and totalitarian political regimes, where national leaders can afford anything. International relations of bipolar era were the relations between rational leaders of democratic states urged to act expediently, and totalitarian leaders of Warsaw Pact able to make any step to ruin the balance.

The most reliable expectations from international partners are based upon so called "prisoner's dilemma": any prisoner separated from his partners and cut out of contacts will act rationally hoping his partners do the same. The situation in the international relations is very similar because the actors never possess full information about the plans of counterpart. But international sphere isn't like prison: the basic treaties are valid and observed thoroughly even under the conditions of crisis; hot lines between governments in crisis periods aren't broken as well. The applicability of "prisoner's dilemma" in international dilemma was doubted. The political actors never communicate like prisoners: they are free in choosing decisions and have lots of resources; prisoners aren't free by default and have no resources except for survival minimum ${ }^{23}$.

The strangest thing was that international analysts didn't give up after discovering this. The next invention was to count out "dynamic dimension of system analysis". In spite of clumsy title it was rather tricky brainstorm to re-schedule the basic parameters: if the establishments and states do officially, the persons responsible for decision making may be influenced personally. To predict these influences coming from various factors became the task for new research program. The negative result from its usage came again from impossibility to rely equally upon different influences: the readiness of responsible persons to observe the law or to trade their advantages admitting breach of the law was the variable impossible to express digitally.

The next attempt was to shorten the expectations from research tools. Okay, maybe no veritable prognosis is viable in the field where freewilling personality acts; but what if the true aim of prognosis is not to foresee it but to count out the best options in further development of political situation? The number of these options is reduced down to the

\footnotetext{
${ }^{23}$ Цыганков П.А. Op. cit. Р. 71-72.
} 
certain number of game play models, so any further development of situation is potentially recognizable.

The answer is that there is no chance to know if the most profitable option is chosen because any actor is not obliged to observe machinery logic, so he can choose the wrong one and follow it stubbornly. On the other hand he can choose one option and then transfer to the next. It is quite possible in non-democratic states, and the usage of these methods was aimed to provide effective withstand with them: so, the only disposal of variables predictable for analysts was if their own state were in war with its ally.

But "democracies do not fight with each other".

\section{Where it all works and what makes us optimistic?}

Another aspect to be covered by fulfilling tasks of prognosis is to predict possible changes of political regimes in certain countries, enabling to act beforehand on behalf of prominent actors of international policy. The previous items discussed in this article covered the strategy of survival in bipolar situation of the Cold War. After having finished it the mankind ran into other problems yet located at the peripheral edge of political science. Moving out terroristic groups and movements to occupy the headlines of news reports led to understanding that both challenges and the strategies of fighting and predicting them have changed.

Political theory had much experience in identifying political regimes as movable constellations of political system's elements. They depend upon economic factors and political culture of the certain society making it more inherent to build up its political regime than if it was guided by logic. The differences in political culture make any agreements harder and can disable any constructive dialog providing situation when the sides of negotiations don't believe each other and think the opposite side is cheating.

The key notion is here the notion of "regime". It bears definite negative connotations linked with negative perception of the fact that social elements defined and conserved by political power may prevail over typically democratic elements of self-organization. The governments where narrow group or one person dominates are usually described as "regimes", democracies aren't ever (except for the USA where usage of 
this notion is very specific). "Regimes" are similar to dictatorships in mass consciousness; in fact, authoritarian and totalitarian regimes are possible under conditions of dictatorship only ${ }^{24}$.

The deal of political theory is here to allocate certain political regime on the scale and to try to predict the chances of its further development according to this allocation.

First issue to be solved here is to find out whether dictatorship of personality or state takes place in case examined. The authoritarianism refers to dictatorship of personality; it is prone to leave people some alternatives and options for personal choice; many fields like cultural and business branches aren't tied. They look more neglected than controlled and people can exercise much activity there unless they try to enter policy. So the conclusion is: authoritarian regime doesn't control its own subjects fully. It makes this regime more ready to negotiations and concessions than totalitarian regime. This one is a dictatorship of the state.

The totalitarianism requires substantial changes in social structures because its difference with authoritarian regime lies in full coverage of social sphere by political control. Hannah Arendt called it "atomization of the society" making faceless "masses" out of individuals ${ }^{25}$. In the USSR the people was called "screws" (in the political system compared to the machine). That means that totalitarian regime requires more serious changes in social structure and thus provides more sustainable dictatorship: dictatorship of state instead of personality.

Authoritarian regime may be destroyed easily if the personality cementing it dies; sometimes the dictator may become a victim of coupd'état organized by his opponents. So the political struggle under the authoritarianism is possible although hidden. Under totalitarianism there is much difference: the dictatorship belongs not to personality but to state. Political opposition is impossible: it is perceived the enemy of life order and its fate is deadly scary. So the opposition is hardly possible and it won't be right to rely upon it. The changes of totalitarian regime may come from economic crush or from defeat in war but not from

${ }^{24}$ Баталов Э.Я. Американская политическая мысль ХХ века. Р. 395; Политология / под ред. М.А. Василика. Р. 233

${ }^{25}$ Арендт Ханна, Джерела тоталітаризму. Р. 373. 
oppositional activity which is never let to come into light and to draw any attention of society.

Authoritarian regimes make flexible police; they are urged to tack both in exterior and interior. Why? The most veritable answer is that these regimes are prone to non-democratic totalitarian regime but they never provide social cohesion satisfying the transformation of the society to "screws". The economic dependence upon democracies of the West plays its role too; states with huge fuel production are less dependent and thus more ready to build totalitarian society. The states allocated far from area of Western democracies are too. At the same time the underdeveloped societies of Latin America lie close to the USA. It makes them dependent upon the US economic and military presence. A number of institutions and interstate organizations like OAS have been established to provide constant linkage between the USA and its partners in Latin America; the traditions of the US military interventions into closest parts of the region (the intervention to Haiti in 1915 lasted 19 years) play their role too.

So the outer factors are too hard to overcome and so they transform to democracies more often. It doesn't make democratic regimes in these countries sustainable but the sense of policy in regions like Latin America is to support democracies wherever they occur. The negative example of Cuba confirms the importance of observance of American interests by support of democracy. On the other hand this support is productive (what is confirmed by the examples of NAFTA and MERCOSUR in the late XX century).

The totalitarian evolution of authoritarianism is possible also if some ideological factors play their role in combination. For instance, in Germany of 1920s the combination of imperialistic revanchist plans and of anti-Semitism led to establishment of Nazi ideology that made German Fascism difficult to defeat ${ }^{26}$. These factors require deeper penetration into people's minds, so it means that ideological preparation for totalitarian transformation takes much time. Totalitarianism is more "perfect" in its essence and thusly much less widespread; true totalitarian regimes are highly resistible to any outer attempts to intrude and to change them even if they are cut off their allies (like Cuba). The economic autarchy is desirable for them because it decreases the harmful influences from

\footnotetext{
${ }^{26}$ Баталов Э.Я. Ор. cit. Р. 30, 167.
} 
democracies onto their integrity provided while trying to affect them in their own interests. It was spotted in the literature that phenomenon of totalitarianism never occurred before XX century although mankind's experience of dictatorship was huge until then. But not a single bit of that experience corresponded to the global trend of XX century: atomization of society mentioned earlier. The dictators' regimes of XIX century never possessed the amount of resistibility the regimes of new age had. Another opinion well-known in the literature is that totalitarianism isn't a global phenomenon; it is possible under the certain conditions of moral political climate which arises coincidentally as a feature of contemporary society but never before and hopefully never again ${ }^{27}$.

The characteristics of totalitarianism include often the depiction of it as of fully developed authoritarianism (driven to the phase of absurdum). The trend able to stop totalitarian tendency is the globalization of economy disabling this trend and making countries prone to build totalitarianism dependent upon international capital and controlled from the outside. However the trends promoting totalitarianism are the religion and the growing of countries with considerable tradition of nondemocratic governance.

The classic region of authoritarianism where totalitarian trends never prevailed and were put into practice in one state only is Latin America (with the military, economic and political support from the USSR) ${ }^{28}$. To make veritable prognosis of chances to change political regime in the certain country we have to research the long-time experience of authoritarian tradition in Latin America where it shaped down in the early XIX century simultaneously with obtaining national independence from Spain. Since that time the entire region demonstrated the features of underdevelopment partly inherited from colonial period and partly caused by the pending competition of development reformist programs throughout XIX century.

In other regions of the globe authoritarian trends evolutioned, changing their meaning and re-surfacing in new combinations with new social groups and classes. But in Latin America the things seem to be

27 Тоталитаризм в Европе XX века. Из истории идеологий, движений, режимов и их преодоления / под ред. Я.С. Драбкина, Н.П. Копылова. Р. 9.

${ }^{28}$ Аллен Роберт. Глобальная экономическая история. Р. 123. 
conserved forever. The authoritarianism there never made sustainable progression to democracy; but it never moved to totalitarianism.

The possible explanation is that authoritarianism in this region is not just a combination of features characterizing the next phase of society's development but a constellation of factors slowing down the progress in the region; these factors haven't been overcome. They turned into "brake factor" under the conditions of reform attempts only; it caused the special character of authoritarianism in Latin America highly different from the analogical regimes in other parts of the world.

\section{CONCLUSIONS}

So now it's time to make some final conclusions concerning the special function of political theory unprecedented by any other science.

In previous centuries there was a serious trend to build up the whole picture of the past to mark the crucial mistakes and make it possible not to repeat them. In history these attempts were stopped very soon with realizing that "history teaches us nothing". There is no chance that future situations repeat previous ones in details. The free-willing people as main actors in history never reload similar events but they went on adding new characteristics of policy, economy and ideology.

We call it "progress" and so our final assumption at the point where we can stop our effort is that progress is the most important reason not to rely upon any prognosis. Progress makes prognoses pointless. Its unpredictable character disables the tries to make sorts of "road maps" for mankind. This seductive prospect - to rely upon plans scheduled beforehand and to make life just the observance of them - is killed along with the attempts to create veritable pictures of the future via prognostic activity.

1. In political theory the prognostic function was designed to fulfill the practical function to predict the possible actions of the enemy in the Cold War.

2. The earliest attempts to work out algorithm of prediction belong to the period of 1940s when the Cold War just has started.

3. These attempts were characterized with the use of mathematics methods and computers. The theory concerning understanding the things 
behind decision-making process of conventional enemy was developed during 1960s.

4. No further effort to count out all the factors influencing the policy of conventional enemy brought up the prognosis with $100 \%$ verity.

5. The failure of these efforts had crucial influence onto the build-up of political theory as a science.

6. The only field of veritable prognoses is concerned to the prediction of political regimes' evolution in certain regions of the globe.

\section{SUMMARY}

The article is devoted to the problem highly actual in the political theory because it aims to fight the negative trends connected with doubtfulness of its practical usage. The model of usage worked out during the period of the Cold War since late 1940s up to 1990s was based upon numerous efforts to find out any sustainable tool to predict the development of situation in international relations. Though dozens of attempts to count out all the possible variables influencing the hypothetic situation, no tool providing $100 \%$ verity has been designed up to date, what decreased the trust put into political theory by politicians. The article explores the successful attempts to predict the evolution of certain political regimes in the countries of the "Third World" belonging to nondemocratic systems.

\section{REFERENCES}

1. Deutsh Karl, Edinger Lewis, Macridis Roy, Merritt Richard. France, Germany and the Western Alliance. N.Y.: Charles Scribner's Sons, 1967. 324 p.

2. Merritt Richard L., Russett Bruce M., Dahl Robert A. Karl Wolfgang Deutsch // The National Academies Press. URL: http:// books.nap.edu/html/biomems/kdeutsh.html\#FOOT4

3. Аллен Роберт. Глобальная экономическая история: краткое введение. М.: Издательство Института Гайдара, 2015. 224 с.

4. Антюхина-Московченко В.И., Злобин А.А., Хрусталев М.А. Основы теории международных отношений. М.: МГИМО, 1988. 141 с.

5. Арендт Ханна. Джерела тоталітаризму. К.: Дух і літера, 2005. $584 \mathrm{c}$. 
6. Баталов Э.Я. Американская политическая мысль XX века. М.: Прогресс-Традиция, 2014. 616 с.

7. Бус Кен. Вызов незнанию: теория международных отношений перед лицом будущего // Теория международных отношений на рубеже столетий / под ред. П.А. Цыганкова. М.: Гардарики, 2002. C. 334-356.

8. Кларк Греневиль, Сон Луис Б. Достижение всеобщего мира через мировое право. Два альтернативних плана // Теория международных отношений на рубеже столетий / под ред. П.А. Цыганкова. М.: Гардарики, 2002. С. 115-137.

9. Класифікатор професій ДК 003: 2010. Х.: Фактор, 2011.

10. Политология / под ред. М.А. Василика. М.: Гардарики, 1999. $600 \mathrm{c}$.

11. Смит Роджер. История гуманитарных наук. М.: ГУ ВШЭ, 2008. 392 c.

12. Современные буржуазные теории международных отношений. Критический анализ / под ред. В.И. Гантмана. М.: Наука, 1976. $486 \mathrm{c.}$

13. Тоталитаризм в Европе $\mathrm{XX}$ века. Из истории идеологий, движений, режимов и их преодоления / под ред. Я.С. Драбкина, Н.П. Копылова. М.: Памятники исторической мысли, 1996. 540 с.

14. Цыганков П.А. Теория международных отношений. М.: Гардарики, 2005. 590 с.

Information about the author: Chekanov V. Yu.

Candidate of historical sciences, Assistant professor of the department of philosophy and history, Taurida V.I. Vernadsky National University, 33 Ivana Kudri str., Kyiv, Ukraine 